\title{
Nitrogen dioxide DOAS measurements from ground and space: comparison of zenith scattered sunlight ground-based measurements and OMI data in Central Mexico
}

\author{
C. RIVERA \\ Facultad de Ciencias, Universidad Nacional Autónoma de México, Circuito Exterior s/n, \\ Ciudad Universitaria, 04510 México, D.F. \\ Corresponding author; e-mail: claudia.rivera@atmosfera.unam.mx \\ W. STREMME and M. GRUTTER \\ Centro de Ciencias de la Atmósfera, Universidad Nacional Autónoma de México, Circuito de la Investigación \\ Científica s/n, Ciudad Universitaria, 04510 México, D.F.
}

Received August 30, 2012; accepted February 22, 2013

\begin{abstract}
RESUMEN
El uso de datos satelitales en combinación con mediciones realizadas en superficie puede proporcionar información valiosa acerca de la química atmosférica y la calidad del aire. En este estudio se comparan mediciones en superficie de dióxido de nitrógeno $\left(\mathrm{NO}_{2}\right)$ realizadas mediante la técnica de espectroscopia óptica de absorción diferencial (DOAS, por sus siglas en inglés) con mediciones del instrumento satelital para la medición de ozono (OMI, por sus siglas en inglés) realizadas de 2006 a 2011. Las mediciones realizadas desde la superficie presentaron grandes variaciones diarias y fueron en promedio tres veces más altas que las columnas medidas desde el espacio. La diferencia se atribuye a una fuerte heterogeneidad horizontal presente en la capa inferior de las columnas de $\mathrm{NO}_{2}$, las cuales fueron muestreadas por el instrumento satelital a partir de un área extensa; de igual manera, esta discrepancia se atribuye a la sensibilidad reducida del satélite cerca de la superficie, donde se encuentran las mayores concentraciones. A partir de los datos del OMI analizados se reconstruyeron mapas de distribución de $\mathrm{NO}_{2}$ sobre el centro de México, y se identificaron tres áreas principales de interés: la zona metropolitana de la Ciudad de México, que fue el área predominante; la zona altamente industrializada de Tula, al norte, y el valle de Cuernavaca, al sur. En este análisis se detectaron de igual forma variaciones estacionales de columnas de $\mathrm{NO}_{2}$ sobre el centro de México: se encontraron columnas más altas durante la estación fría y seca, seguidas por las de la estación caliente y seca; las columnas más bajas se encontraron durante la época de lluvias. Este conjunto de datos evidencia el transporte de contaminación de este gas desde Tula hasta la Ciudad de México, así como al Valle de Cuernavaca.
\end{abstract}

\begin{abstract}
The use of satellite data in combination with ground-based measurements can provide valuable information about atmospheric chemistry and air quality. In this study, ground-based Differential Optical Absorption Spectroscopy (DOAS) measurements of nitrogen dioxide $\left(\mathrm{NO}_{2}\right)$ conducted in central Mexico are compared with the space-borne Ozone Monitoring Instrument (OMI) dataset of 2006-2011. Ground-based measurements exhibited large day-to-day variations and were on average three times higher than the space-borne derived average over the observation site. This difference is attributed to strong horizontal inhomogeneity of the lower layer of the measured $\mathrm{NO}_{2}$ columns, sampled over a large footprint from the satellite instrument. Also, a reduced sensitivity of the satellite observation near the surface, where the largest concentrations are expected, could be responsible for this large discrepancy. From the analyzed OMI dataset, distribution maps of $\mathrm{NO}_{2}$ above central Mexico were reconstructed, allowing to identify three main areas with increased $\mathrm{NO}_{2}$ column densities: The dominating metropolitan area of Mexico City, the heavily industrialized region of Tula
\end{abstract}


to the north and the Cuernavaca valley to the south. In this analysis, seasonal variability of $\mathrm{NO}_{2}$ columns over central Mexico was detected, finding higher $\mathrm{NO}_{2}$ columns during the dry and cold season, followed by the dry and warm period, and finally the lowest $\mathrm{NO}_{2}$ columns were found during the rainy season. Pollution transport of this gas from Tula into Mexico City, as well as towards the Cuernavaca valley, is evident from this dataset.

Keywords: DOAS, OMI, nitrogen dioxide, ground-based, space-borne, central Mexico.

\section{Introduction}

Mexico City is the third largest city of the world, with more than 20 million inhabitants (UN, 2012). It is located at $19.4^{\circ} \mathrm{N}$ latitude and approximately at an elevation of $2200 \mathrm{~m}$ above sea level (masl). For several years Mexico City has experienced severe air quality problems, which have been addressed by authorities trough the implementation of various programs. While the countermeasures and technological improvements have effectively decreased the amount of some pollutants, the city continues to experience pollution episodes resulting on the frequent violation of air quality standards.

Nitrogen dioxide $\left(\mathrm{NO}_{2}\right)$ plays a major role in tropospheric and stratospheric chemistry (Crutzen, 1979). In polluted regions such as Mexico City, tropospheric $\mathrm{NO}_{2}$ concentrations can be highly variable in time and space and are influenced by both natural and anthropogenic emissions. In Mexico City, most of the $\mathrm{NO}_{2}$ present in the atmosphere comes from fossil fuel combustion from transportation and partly from industrial activities. $\mathrm{NO}_{2}$ levels in Mexico City have decreased by $30 \%$ between 1990 and 2008, and the average surface concentration registered in 2008 by four stations around the Universidad Nacional Autónoma de México (UNAM) campus in Mexico City-where the ground-based measurements presented in this study were conducted-was $56.8 \mathrm{ppb}$ (SMA-GDF, 2010).

Satellites provide global observations, allowing to retrieve information from nearly every region in the globe (Rees, 2001). There are a number of instruments measuring from space, covering a wide range of wavelengths, with different spatial resolution and viewing geometries. In this work we have focused on the Ozone Monitoring Instrument (OMI) (Levelt et al. 2006a, b), a UV-VIS spectrometer on board NASA's Earth Observing System-Aura satellite, able to provide a daily global coverage.

Data from the OMI instrument have been used in an extensive number of studies involving different atmospheric gases as $\mathrm{NO}_{2}, \mathrm{O}_{3}, \mathrm{SO}_{2}, \mathrm{HCHO}$, among others (Bhartia, 2002; Chance, 2002). The $\mathrm{NO}_{2}$ data products provide information about total and tropospheric $\mathrm{NO}_{2}$ columns. The $\mathrm{NO}_{2}$ dataset in particular, has been validated in different studies. Celarier et al. (2006) compared $\mathrm{NO}_{2}$ columns from OMI with $\mathrm{NO}_{2}$ columns measured by the Système d'Analyse par Observation Zénithale (SAOZ) network, finding good agreement between the two of them although the measurements were not done at the same time. As a continuation, the different measurements and validation activities for $\mathrm{OMI} \mathrm{NO}_{2}$ stratospheric, tropospheric and total columns using ground- and aircraft-based measurements were summarized by Celarier et al. (2008). Good agreement was reported between OMI and nearby instruments, finding correlations higher than 0.6 with ground-based instruments, whereas $\mathrm{OMI} \mathrm{NO}_{2}$ stratospheric and total columns were found to be underestimated by 14 and $15-30 \%$, respectively.

During the Dutch Aerosol and Nitrogen Dioxide Experiments for Validation of OMI and SCIAMACHY (DANDELIONS) 2005 and 2006 field experiments in the Netherlands, Brinksma et al. (2008) found good agreement between tropospheric $\mathrm{NO}_{2}$ from OMI and MAX-DOAS (Multi-AXis), as well as between total $\mathrm{NO}_{2}$ from $\mathrm{OMI}$ and direct sun observations. Boersma et al. (2008) compared $\mathrm{OMI} \mathrm{NO}_{2}$ tropospheric columns with in situ aircraft measurements during the INTEX-B campaign, the results showed good correlation with no significant bias between the two data sets. Irie et al. (2008) used MAX-DOAS measurements to validate OMI $\mathrm{NO}_{2}$ columns during the Mount Tai Experiment 2006 finding that OMI data may have a positive bias of $20 \%$ over the North China Plain. Gruzdev and Elokhov (2010) found that tropospheric OMI $\mathrm{NO}_{2}$ columns measured over Zvenigorod, Russia were approximately $40 \%$ lower than ground-based twilight measurements. Vlemmix et al. (2010) compared tropospheric ground-based measured $\mathrm{NO}_{2}$ columns with OMI-satellite tropospheric $\mathrm{NO}_{2}$ data finding no significant difference and a correlation of 0.88 . 
Ionov et al. (2008) conducted a geophysical validation of $\mathrm{OMI} \mathrm{NO}$ 2 vertical column measurements with collocated ground-based observations at two stations in central Asia and Europe finding that mid-latitude OMI stratospheric $\mathrm{NO}_{2}$ column data underestimates ground-based measurements.

Direct-Sun mode measurements have been conducted as well in order to validate $\mathrm{OMI} \mathrm{NO}$ columns. Wenig et al. (2008) used direct-Sun mode Brewer measurements to conduct a validation study with OMI tropospheric $\mathrm{NO}_{2}$ columns concluding that monthly averages of coinciding measurements yielded a correlation of 0.9 , however OMI data was $25 \%$ lower than the ground-based Brewer measurements. Herman et al. (2009) conducted intercomparisons of $\mathrm{NO}_{2}$ columns measured with ground-based direct solar irradiance measurements to $\mathrm{OMI} \mathrm{NO} 2$ columns finding good agreement (correlation of 0.73 ).

Regional and global models have also been used to compare and validate $\mathrm{OMI} \mathrm{NO}_{2}$ tropospheric columns (Kim et al., 2009; Herron-Thorpe et al., 2010; Huijnen et al., 2010; Dirksen et al., 2011) and to estimate NOx emissions from different sources (Lin, 2012). Recently, Beirle et al. (2011) studied NOx emissions and lifetimes from megacities and power plants, while Valin et al. (2011) used the super-zoom mode of OMI to observe $\mathrm{NO}_{2}$ slant columns from point sources and two cities, capturing significant spatial variability at fine scales.

In this work, the $\mathrm{OMI} \mathrm{NO}_{2}$ data product (OMI/ Aura nitrogen dioxide total and tropospheric column 1-orbit L2 swath $13 \times 24 \mathrm{~km}$, data set version 003 ) has been analyzed and compared to ground-based measurements conducted at UNAM campus in Mexico City. $\mathrm{NO}_{2}$ column maps were reconstructed from the OMI data product using an algorithm based on the optimal estimation approach with a weighted assignment of the measurement onto a fine grid, in order to identify the spatial features of its distribution with higher resolution. Focus has been given to the study of $\mathrm{NO}_{2}$ mainly to its role as a catalyst in the production of tropospheric ozone $\left(\mathrm{O}_{3}\right)$, which is responsible for one of the most severe air quality problems in the Mexico City metropolitan area (MCMA).

\section{Data set}

\section{$2.1 \mathrm{OMI}$}

OMI is a nadir viewing spectrometer covering a spectral region of 264-504 nm, conducting atmospheric chemistry measurements with a resolution of 0.42 $0.63 \mathrm{~nm}$ since 2004 on board NASA's Earth Observation System (EOS)-Aura satellite. Aura follows a sun-synchronous polar orbit (705 km altitude), with an ascending local equator crossing time at 13:45. OMIs observations provide complete global coverage in one day with a nominal ground footprint of $13 \times$ $24 \mathrm{~km}^{2}$ at nadir (OMI Team, 2009). It measures a number of air quality components such as $\mathrm{NO}_{2}, \mathrm{SO}_{2}$, $\mathrm{BrO}, \mathrm{HCHO}$, and aerosols (Levelt et al. 2006a, b).

The OMI operational algorithm is described in detail by Bucsela et al. (2006). For the evaluation of spectra recorded by OMI, a similar DOAS method (Platt and Stutz, 2008) is used as for the ground instruments. In this method a spectral fit is applied to all measured spectra. The evaluation of spectra results on slant column densities (SCDs) for each viewing pixel. The computed SCDs are then converted to vertical column densities (VCDs) using an air mass factor (AMF). The AMF is the ratio between the retrieved SCD and the VCD. The AMF concept was introduced by Solomon et al. (1987) and is dependent on clouds and aerosols, as well as viewing geometries and surface albedo.

In this work, the OMI/Aura nitrogen dioxide total and tropospheric column 1-orbit L2 swath $13 \times 24 \mathrm{~km}$, data set version 003, level 2, algorithm version 1.1.4.4 data product was downloaded from NASA's Goddard Earth Sciences Data and Information Services Center (GESDISC) using the MIRADOR 1.42 tool (http:// disc.sci.gsfc.nasa.gov/Aura/data-holdings/OMI). We have analyzed the dataset and only considered total $\mathrm{NO}_{2}$ columns from cloud fraction below $20 \%$ over the period 2006-2011. This dataset has been reprocessed and released on December 2011 (Claas, 2012).

\subsubsection{Reconstruction of the mean column $\mathrm{NO}_{2}$ dis- tribution}

The mean column $\mathrm{NO}_{2}$ distribution over a fine grid (of the order of about $2 \mathrm{~km}$ ) can be reconstructed from measurements done on a larger footprint (here $13 \times 24 \mathrm{~km}^{2}$ for OMI), solving the mathematically ill-posed problem $\mathbf{Y}=\mathbf{K} \mathbf{x}+\boldsymbol{\varepsilon}$. In this equation, $\mathbf{Y}$ represents the vector containing all $\mathrm{OMI} \mathrm{NO}_{2}$ measurements, $\mathbf{x}$ is the solution vector which contains the estimation of the mean column $\mathrm{NO}_{2}$ distribution on the chosen grid, $\boldsymbol{\varepsilon}$ represents the deviation between a column measured/retrieved from the space 
measurement and the estimated mean value. $\boldsymbol{E}$ is mainly dependent on the day-to-day variance, but also on the seasonal variance and measurement precision. The matrix $\mathbf{K}$ describes how the measurements are related with the mean gas horizontal distribution. It represents a forward model that reproduces mainly the footprint of the OMI instrument $\left(13 \times 24 \mathrm{~km}^{2}\right.$ at nadir). The reconstruction uses a Tihkonov-smoothing-constraint, similar as the one used for profile retrievals or in image restoration. Further details of this method can be found in Stremme et al. (2013).

\subsection{Zenith scattered sunlight DOAS}

Ground-based DOAS measurements were conducted at the UNAM campus in Mexico City $\left(19.33^{\circ} \mathrm{N}\right.$, $99.18^{\circ} \mathrm{W}$ ) between August 2010 and December 2011. Scattered light was collected by means of a telescope and transferred into an Ocean Optics TR2000 spectrometer with a spectral resolution of $\sim 0.6 \mathrm{~nm}$ and wavelength coverage of 291-501 nm. Spectra were taken every minute using the DOASIS software (Kraus, 2006) and were evaluated using the QDOAS (version 1.00) software (Fayt et al., 2011). Differential cross-sections of $\mathrm{NO}_{2}$ at $298 \mathrm{~K}$ (Vandaele et al., 1998), $\mathrm{O}_{3}$ at $221 \mathrm{~K}$ and $241 \mathrm{~K}$ (Burrows et al., 1999), the oxygen dimer $\mathrm{O}_{4}$ (Hermans et al., 1999) and a Ring spectrum, generated at $273 \mathrm{~K}$ from a high resolution Kurucz file using the QDOAS software (Fayt et al., 2011) were included in the analysis. The oxygen dimer $\mathrm{O}_{4}$ was included in the evaluation procedure in order to detect enhancement on the light path of the measurements since it is expected to have a constant concentration in the atmosphere. Evaluations were conducted in the 405 and $465 \mathrm{~nm}$ wavelength ranges with a fixed reference spectrum measured on 21 December 2011 at 14:21 local time (LT) under clear sky and high ventilation conditions for the whole time series. Geometrical AMFs were calculated and used to convert SCDs to VCDs for further comparison with OMI results. For this it was considered that the light path through a trace gas layer varies with $1 / \cos \theta$, where $\theta$ is the solar zenith angle (Chen et al., 2009). It should be noted that this simplified approach without the use of a full radiative transfer calculation that effectively incorporates scattering processes, reflection on the earth's surface, refraction, the curvature of the earth, the vertical distribution of trace gases and the influence of aerosols leads to additional errors discussed in detail by Platt and Stutz (2008).

\subsection{Surface measurements}

Since 1986, a network of 34 stations run by the local government (Red Automática de Monitoreo Atmosférico, RAMA) reports continuous and permanent measurements of concentrations of $\mathrm{O}_{3}$, sulfur dioxide $\left(\mathrm{SO}_{2}\right)$, nitrogen oxides (NOx), carbon monoxide (CO) and particulate matter PM10 and PM2.5 to evaluate air quality in the metropolitan area. All data generated by RAMA are freely available online at http://www. calidadaire.df.gob.mx/. $\mathrm{NO}_{2}$ is determined using a nitrogen oxides analyzer based on the chemiluminescence measurement technique. For this study $\mathrm{NO}_{2}$ concentration results generated during 2010 and 2011 by Pedregal $\left(19.32^{\circ} \mathrm{N}, 99.20^{\circ} \mathrm{W}\right)$, Tlalpan $(19.25 \mathrm{~N}$, 99.18 W), Santa Úrsula $\left(19.31^{\circ} \mathrm{N}, 99.14^{\circ} \mathrm{W}\right)$, Merced $\left(19.42^{\circ} \mathrm{N}, 99.11^{\circ} \mathrm{W}\right)$ and FES Acatlán $\left(19.48^{\circ} \mathrm{N}\right.$, $\left.99.24^{\circ} \mathrm{W}\right)$ stations situated close to the study site were used to calculate $\mathrm{NO}_{2}$ columns, using mixing layer heights (section 2.4) as well as pressure and temperature data (section 2.5).

\subsection{LIDAR}

A Vaisala CL31 ceilometer, an active instrument based on the LIDAR (light detection and ranging) measurement technique, was used to measure backscattered aerosol density at the UNAM campus, allowing the estimation of mixing layer heights. The measurement principle involves the transmission of pulsed laser radiation into the atmosphere, which is further backscattered and detected with a certain time delay. The measurement range of the instrument used in this field study was from 0 up to $7500 \mathrm{~m}$ above the ground with a $10 \mathrm{~m}$ resolution. The LIDAR wavelength of $905 \mathrm{~nm}$ was provided by an InGaAs MOCVD laser diode, $110 \mathrm{~ns}, 1.2 \mu \mathrm{J}$ per pulse, and repetition rate of $8192 \mathrm{~Hz}$. The mixing height was retrieved using the CL31 MLH software based on the gradient method, which is focused on selecting the maximum of the negative gradient of the backscatter coefficient $(\beta)$ to be the top of the mixed layer $(-\mathrm{d} \beta / \mathrm{d} x)$. A more detailed description of this methodology can be found in Münkel et al. (2007).

\subsection{Meteorological parameters}

Meteorological parameters were recorded by a Davis Vantage Pro 2 station installed at the UNAM campus, forming part of the Programa de Estaciones Meteorológicas del Bachillerato Universitario (PEMBU) network. From the dataset recorded by 

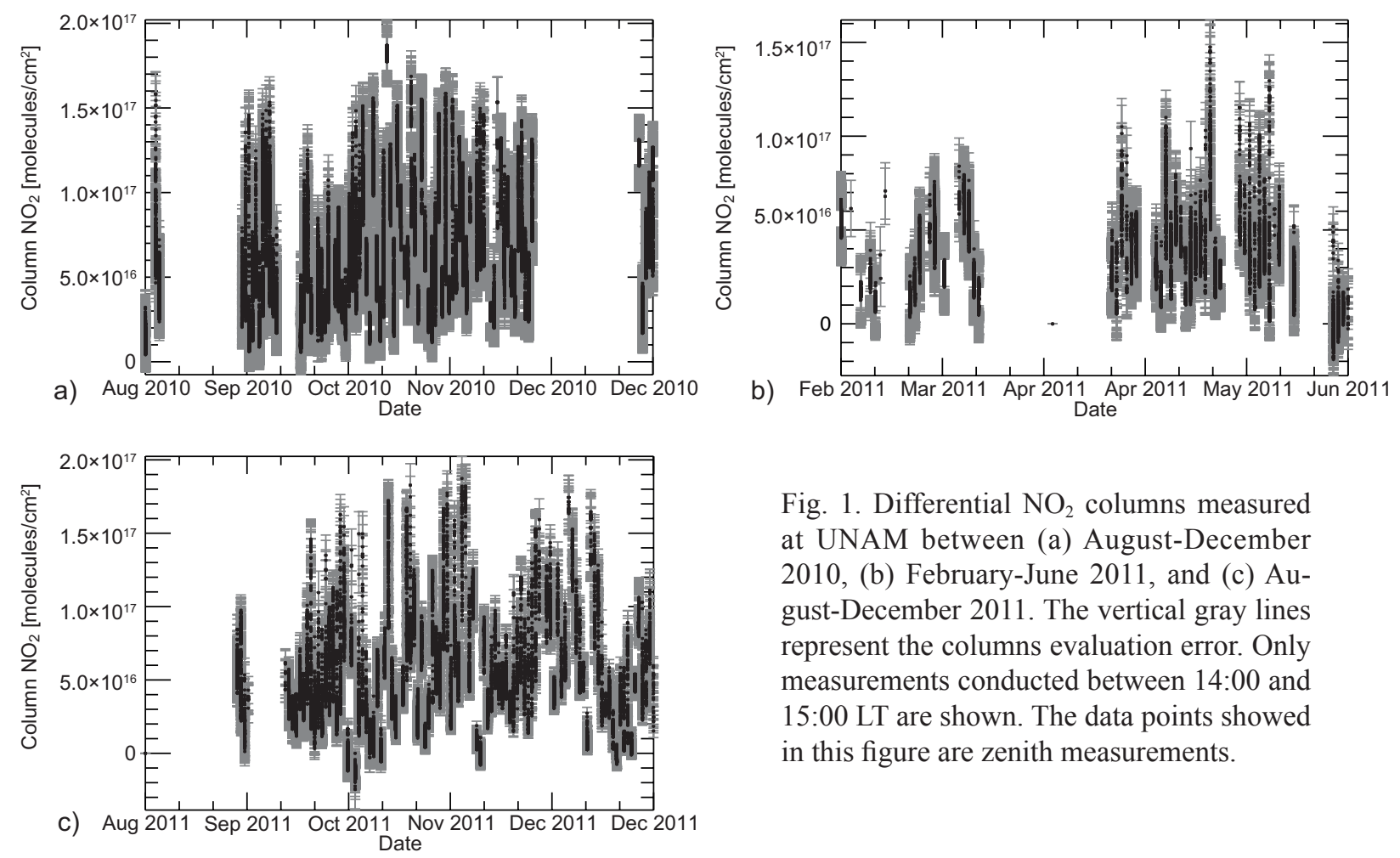

Fig. 1. Differential $\mathrm{NO}_{2}$ columns measured at UNAM between (a) August-December 2010, (b) February-June 2011, and (c) August-December 2011. The vertical gray lines represent the columns evaluation error. Only measurements conducted between 14:00 and 15:00 LT are shown. The data points showed in this figure are zenith measurements.

the meteorological station, pressure and temperature were used for the calculation of ground-based $\mathrm{NO}_{2}$ columns based on $\mathrm{NO}_{2}$ concentrations measured by the RAMA network.

\section{Results and discussion}

\subsection{Ground-based $\mathrm{NO}_{2}$ columns}

Figure 1 shows differential $\mathrm{NO}_{2}$ columns measured at UNAM between August 2010 and December 2011. The gaps in the graph represent periods where no measurements were conducted, either due to experimental problems, or periods of cloudiness or rain identified through the analysis of the data itself using evaluation results of the oxygen dimer. Only measurements conducted between 14:00 and 15:00 LT are plotted in order to depict columns coincident with OMI overpasses ( 14:21 LT) over Mexico City. Large variability on day-to-day $\mathrm{NO}_{2}$ columns was measured, illustrating the dynamics of fresh emissions and rapid conversion of pollutants occurring in the study area. The ground-based average $\mathrm{NO}_{2}$ column values and standard deviation measured from August 2010 to December 2011 between 14:00 and 15:00 LT was $(5.61 \pm 3.32) \times 10^{16}$ molecules $/ \mathrm{cm}^{2}$.

The average diurnal behavior of differential $\mathrm{NO}_{2}$ columns measured at UNAM on the same measure- ment period are presented in Figure 2. The maximum of the measured $\mathrm{NO}_{2}$ differential columns is found around noon, which is consistent with the reported hourly NOx emissions for the MCMA by the official inventory (SMA-GDF, 2010).

\section{2 $\mathrm{NO}_{2}$ spatial distribution}

The average distribution of $\mathrm{NO}_{2}$ total columns derived from OMI measurements conducted between

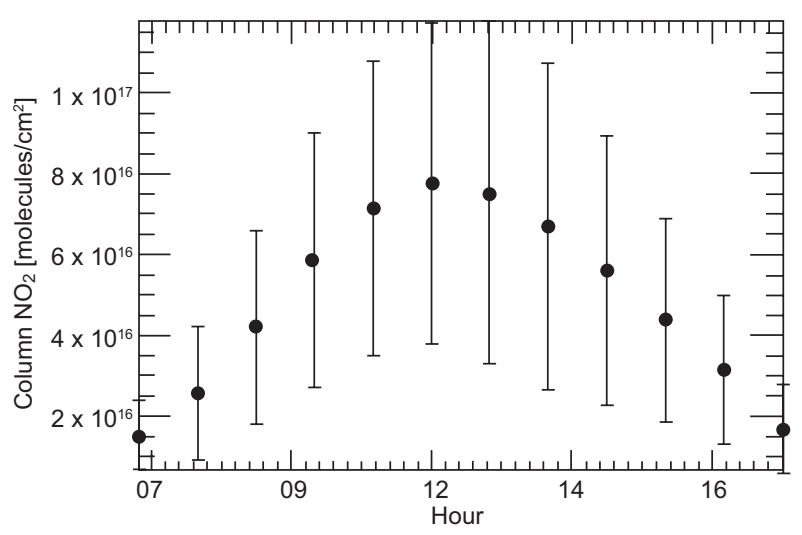

Fig. 2. Averaged hourly differential $\mathrm{NO}_{2}$ columns measured at UNAM over the whole time period (August 2010 to December 2011). The vertical grey lines represent the column standard deviation. 
June 2006 and December 2011 over the Mexico basin is depicted in Figure 3. Higher $\mathrm{NO}_{2}$ total columns are observed in the downtown area of Mexico City, which gradually decrease with distance from the city center. The average and standard deviation of all $\mathrm{OMI} \mathrm{NO}$ columns measured over UNAM during 2010-2011 at its overpass time, $\sim 14: 21$, is $(1.18 \pm 1.1) \times 10^{16}$ molecules $/ \mathrm{cm}^{2}$. While Figure 3 is simply the average of the columns falling on each grid point, Figure 4 shows a reconstruction of the mean column gas distribution according to the methodology described in section 2.1.1. The reconstructed value of the average over UNAM for the same time period is $1.7 \times 10^{16}$ molecules $/ \mathrm{cm}^{2}$. A clear difference can be observed between the average and reconstructed column gas distributions with the average column being smaller over UNAM. This bias is present during all seasons, it might originate from the sensitivity of the spaceborne measurements to pollution near the surface and is discussed in more detail in section 3.3.

\subsubsection{Three main areas of interest in central Mexico} From Figures 3 and 4, three main areas of interest in central Mexico can be identified: the Tula industrial area to the north, a dominating blur centered around Mexico City, and the Cuernavaca valley to the south. However, the reconstructed map in Figure 4 allows to better appreciate the finely defined areas where either $\mathrm{NO}_{2}$ columns are enhanced or diminished over the

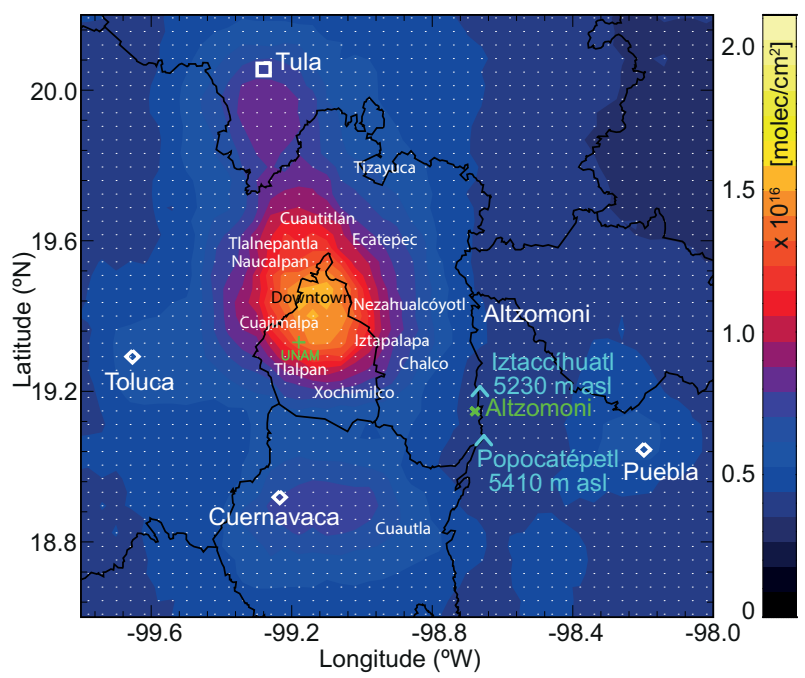

Fig. 3. Averaged $\mathrm{NO}_{2}$ total columns distribution derived from OMI measurements conducted between June 2006 and December 2011 over the Mexico basin. Scale from (0 to 2.2$) \times 10^{16}$ molecules $/ \mathrm{cm}^{2}$.

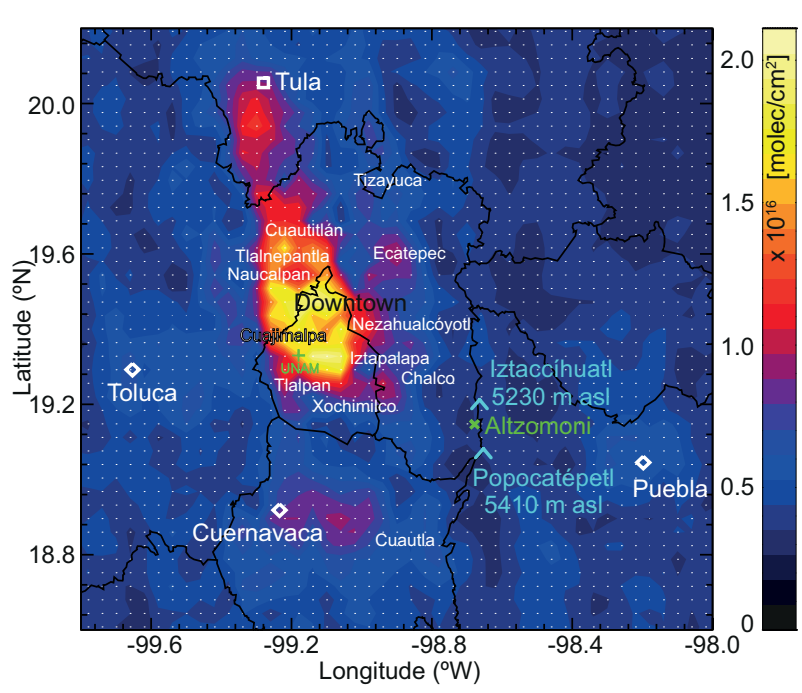

Fig. 4. $\mathrm{NO}_{2}$ total columns distribution reconstructed from OMI measurements (see section 2.2.1) conducted between June 2006 and December 2011. Same scale as Figure 3.

studied area. Lacustrian and mountainous areas inside the MCMA are, for instance, more clearly observed in Figure 4 than in Figure 3. Also, the industrial and more densely populated areas are better defined as well.

Unique distribution structures of $\mathrm{NO}_{2}$ columns above the MCMA were identified through the reconstruction of mean $\mathrm{NO}_{2}$ column distribution in Figure 5a. $\mathrm{NO}_{2}$ column enhancements can be observed on the northern and central parts of the city, which are characterized by intense and heavy traffic (central and northern parts, respectively) and industrial activities (northern part). On the southern, eastern and western sides, the $\mathrm{NO}_{2}$ columns tend to decrease with distance of the city center, while on the northern part, the enhancement of $\mathrm{NO}_{2}$ columns is even extended towards the Tula industrial area (Fig. 5b), from which a clear footprint was observed and differentiated from the MCMA.

The region around Tula shown in Figure $5 \mathrm{~b}$, is located in the state of Hidalgo, $\sim 50 \mathrm{~km}$ northwest of Mexico City. It is characterized by the presence of a power plant, a refinery, several cement works and other manufacturing industries. The OMI footprint clearly shows higher $\mathrm{NO}_{2}$ column values close to the industries. As in the case of the MCMA, the $\mathrm{NO}_{2}$ column enhancement gradually decreases with distance of the pollution sources with an increase of $\mathrm{NO}_{2}$ columns towards Mexico City. From Figure 5b, an empiric dispersion pattern of the plume of the Tula industrial complex towards the southeast can be inferred. This result is consistent with previous studies using 

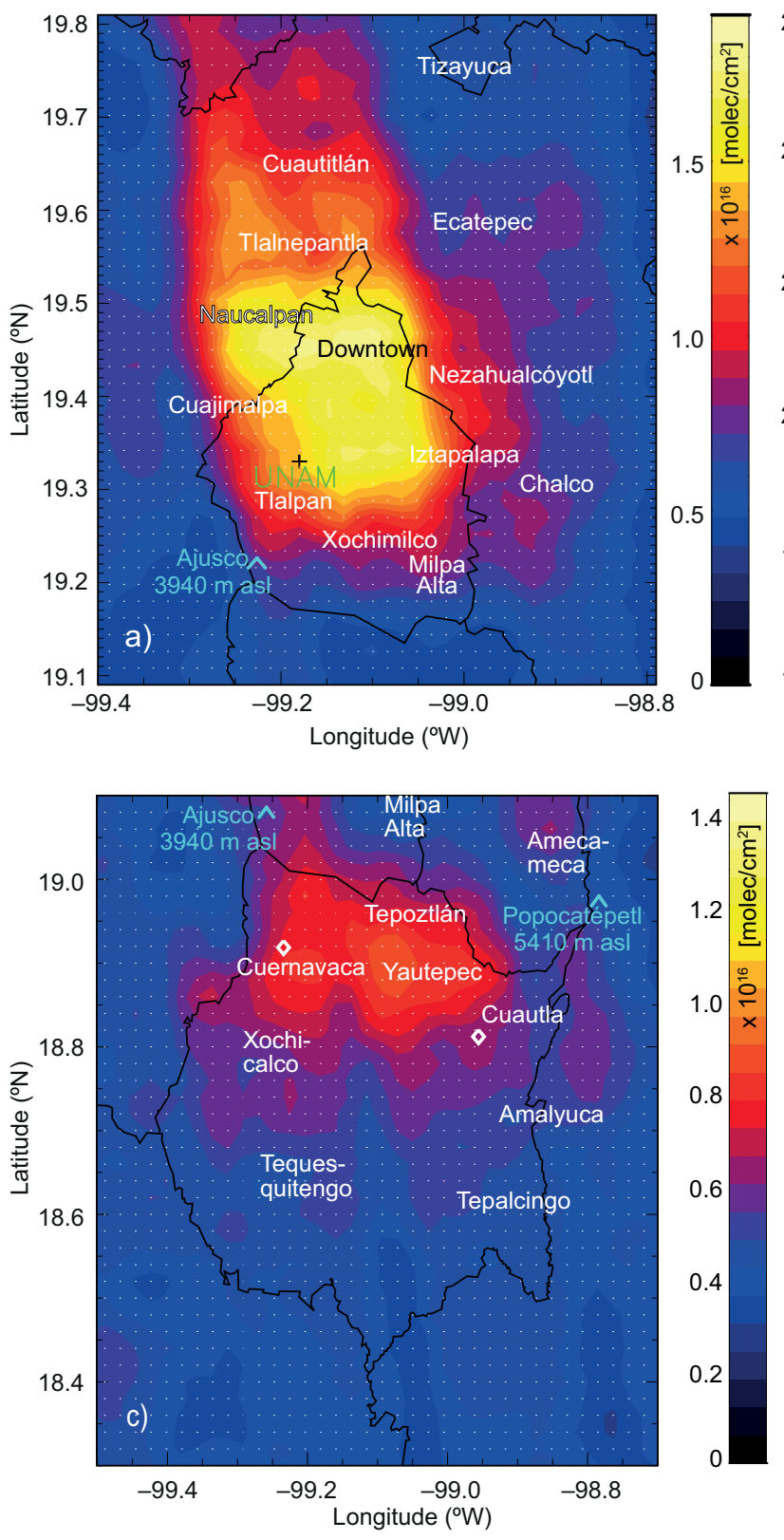

dispersion models addressing the transport of the emissions from the Tula industrial complex towards the MCMA(CCA-UNAM, 2008; de Foy et al., 2009).

The third identified area in central Mexico where a clear, though less intense $\mathrm{NO}_{2}$ column enhancement is observed, is the Cuernavaca valley shown in Figure $5 \mathrm{c}$. This result was somewhat unexpected when compared to the relatively small column enhancements observed above the cities of Puebla and Toluca, which are similar to Cuernavaca in terms of population and industrial activity. Cuernavaca valley, however, is much lower in altitude $(<1500$ masl), host of

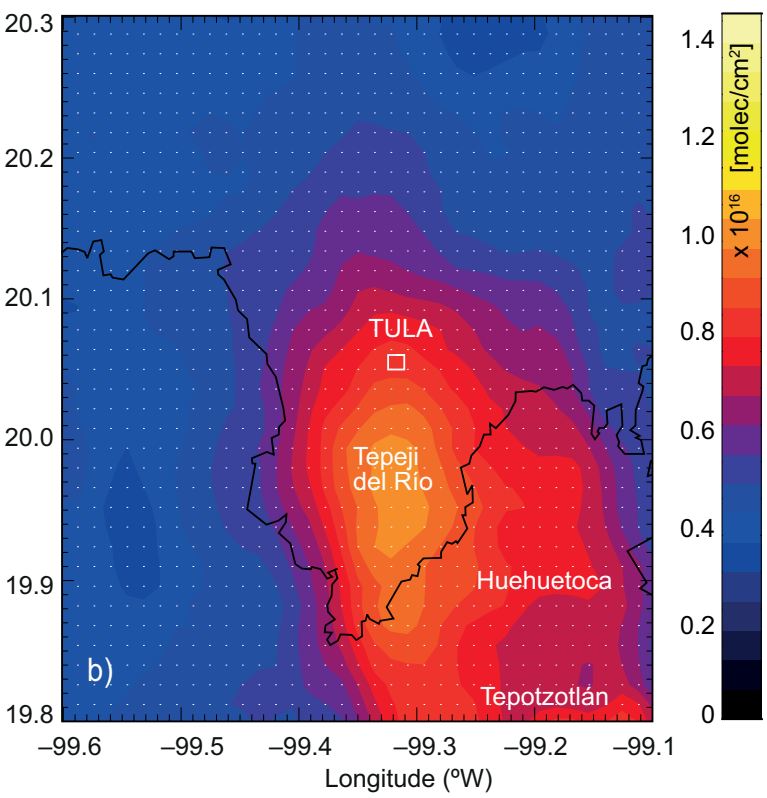

Fig. 5. $\mathrm{NO}_{2}$ total columns distribution over different areas of central Mexico reconstructed from OMI measurements conducted between June 2006 and December 2011. (a) The Mexico City metropolitan area; (b) the heavily industrialized region around Tula, Hidalgo; and (c) the Cuernavaca valley. Note that different scales have been used in the plots. a large number of sugar cane plantations. During the industrial processing and harvesting intense biomass burning is practiced, which could explain the increased $\mathrm{NO}_{2}$ column values observed with the OMI instrument. Another possible explanation is the impact of emissions by the surrounding states. Recently Salcedo et al. (2012) reported an efficient transport of ozone and its precursors to this area by the surrounding Mexico City and Puebla state, while Melamed et al. (2009) detected during a study in 2006, $\mathrm{NO}_{2}$ transport events southeast of Mexico City from and towards the Cuautla region. 


\subsubsection{Seasonal variability}

An additional approach was used analyzing OMI data into three different seasons: (1) dry and cold covering the months of November, December, January and February; (2) dry and warm for the months of March, April and May; and (3) the rainy season including the months of June, July, August, September and October. Figure 6 depicts $\mathrm{NO}_{2}$ total column distributions reconstructed from OMI measurements conducted between June 2006 and December 2011 for the dry and cold (Fig. 6a), dry and warm (Fig. 6b) and rainy seasons (Fig. 6c). The same scale is used in all three plots for comparison. Higher $\mathrm{NO}_{2}$ columns were measured during the dry and cold season, followed by the dry and warm period and finally the lowest $\mathrm{NO}_{2}$ columns were found during the raining season. For the dry-cold and dry-warm seasons the pattern is confirmed by the ground-based measurements at UNAM (Fig. 7). Wallace and Kanaroglou (2009) have reported sensitivity of OMI to subtle temperature changes, while Boersma et al. (2009) observed $\mathrm{NO}_{2}$ columns 1.6-2.7 times higher in winter than in summer in Israeli cities. The atmospheric stability characteristic of the dry and cold season promotes a larger number of molecules to be present in the studied area, while during the raining season, water is mainly responsible for the removal of pollutants in the atmosphere.

The $\mathrm{NO}_{2}$ total column distribution reconstructed during the rainy season (Fig. 6c) allows to better identify the presence of areas with $\mathrm{NO}_{2}$ column enhancements over the cities of Toluca and Puebla, whose contribution is somewhat lost by the large
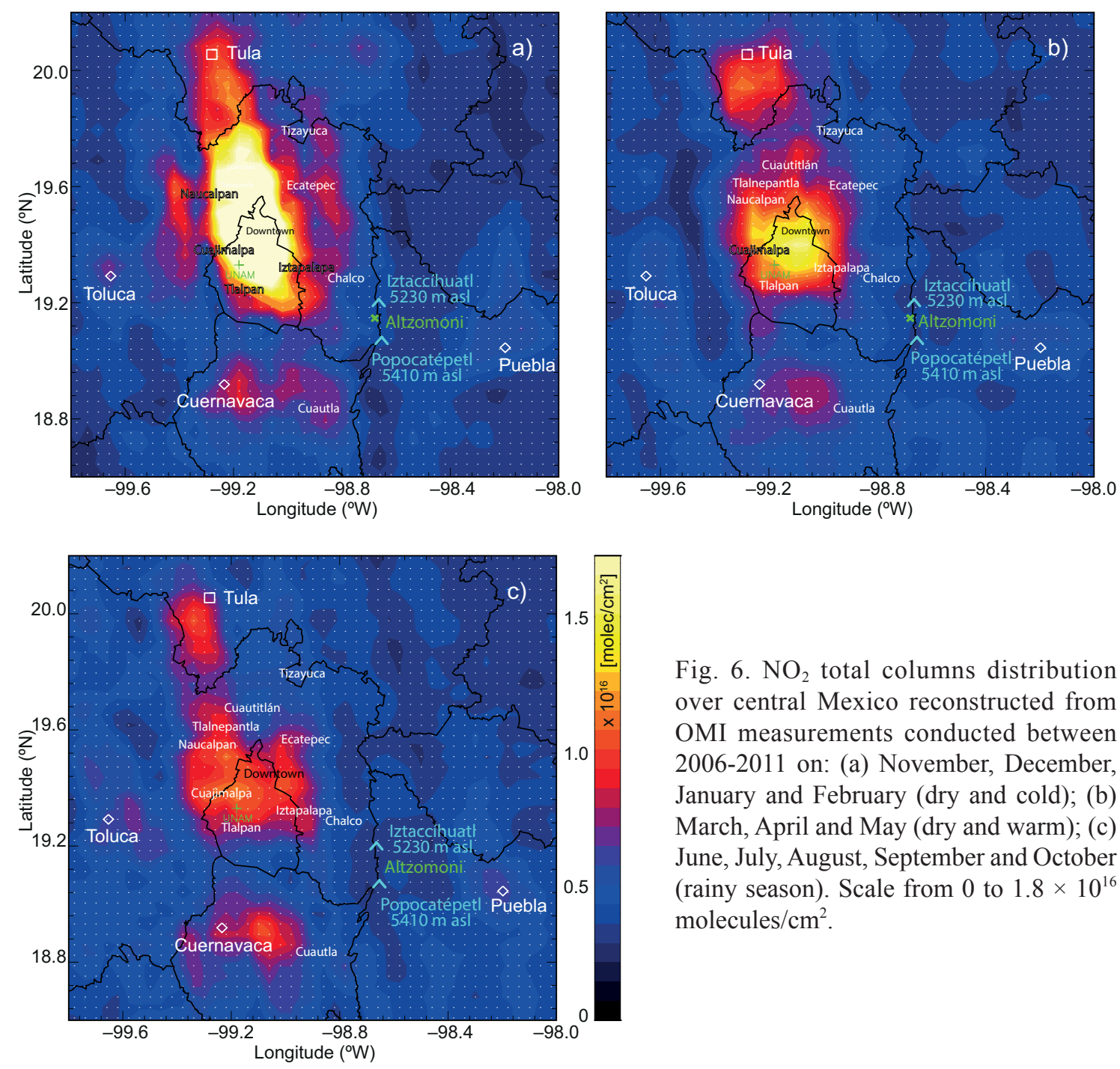

Fig. 6. $\mathrm{NO}_{2}$ total columns distribution over central Mexico reconstructed from OMI measurements conducted between 2006-2011 on: (a) November, December, January and February (dry and cold); (b) March, April and May (dry and warm); (c) June, July, August, September and October (rainy season). Scale from 0 to $1.8 \times 10^{16}$ molecules $/ \mathrm{cm}^{2}$. 


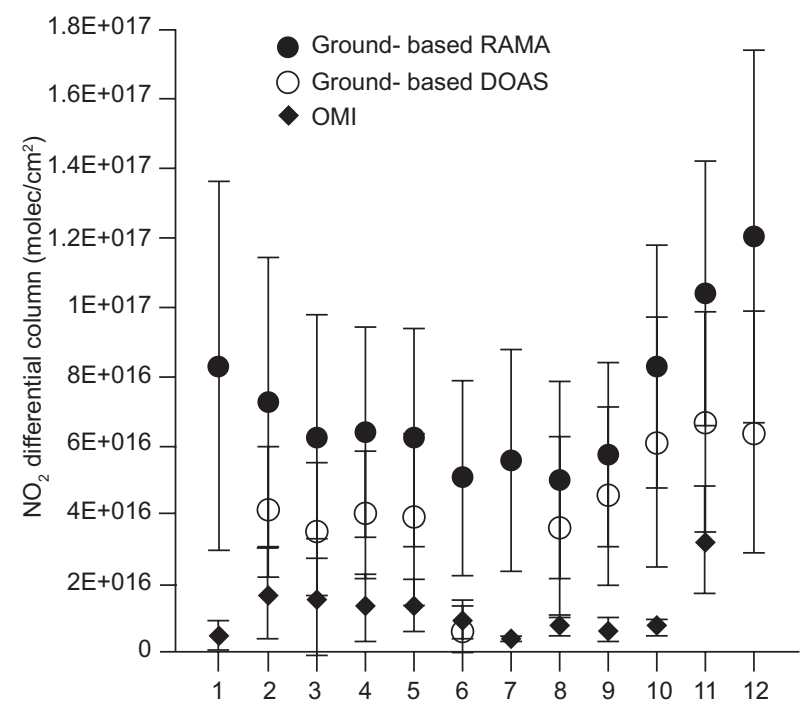

Fig. 7. Monthly average comparison between groundbased, OMI and RAMA (calculated) $\mathrm{NO}_{2}$ columns.

column densities measured over the MCMA, the Tula industrial area or even the Cuernavaca valley during other months of the year. Also, a transport between the MCMA and Cuernavaca is visible during the dry seasons both through the Cuautla and Cuernavaca sides, where the highway connecting both cities runs. This confirms the pollution transport highlighted in the previous section and addressed by previous studies (Melamed et. al., 2009; Salcedo et al., 2012).

\subsection{Comparison of ground-based and space-borne measurements}

A comparison of direct coincident measurements was done for $\mathrm{NO}_{2}$ ground-based and OMI measured columns. All ground-based measurements conducted during the overpass time of OMI over UNAM $(\sim 14: 21$ LT) were used with a tolerance of $\pm 20 \mathrm{~min}$. OMI measurements having a pixel center within a certain radius are used. The number of coincident days for the direct comparison is increasing when using larger radius. Ground-based and OMI measurements conducted on the coincident days and times were averaged and are reported in Table I along with its standard deviation, correlation coefficient, linear-fit offset and linear-fit slope. In general, ground-based measured $\mathrm{NO}_{2}$ columns were 2.7-6 times higher than OMI measured columns, which could be explained by the spatial discrepancy between the ground-based measurements (basically local) and the satellite averaged measurements. The

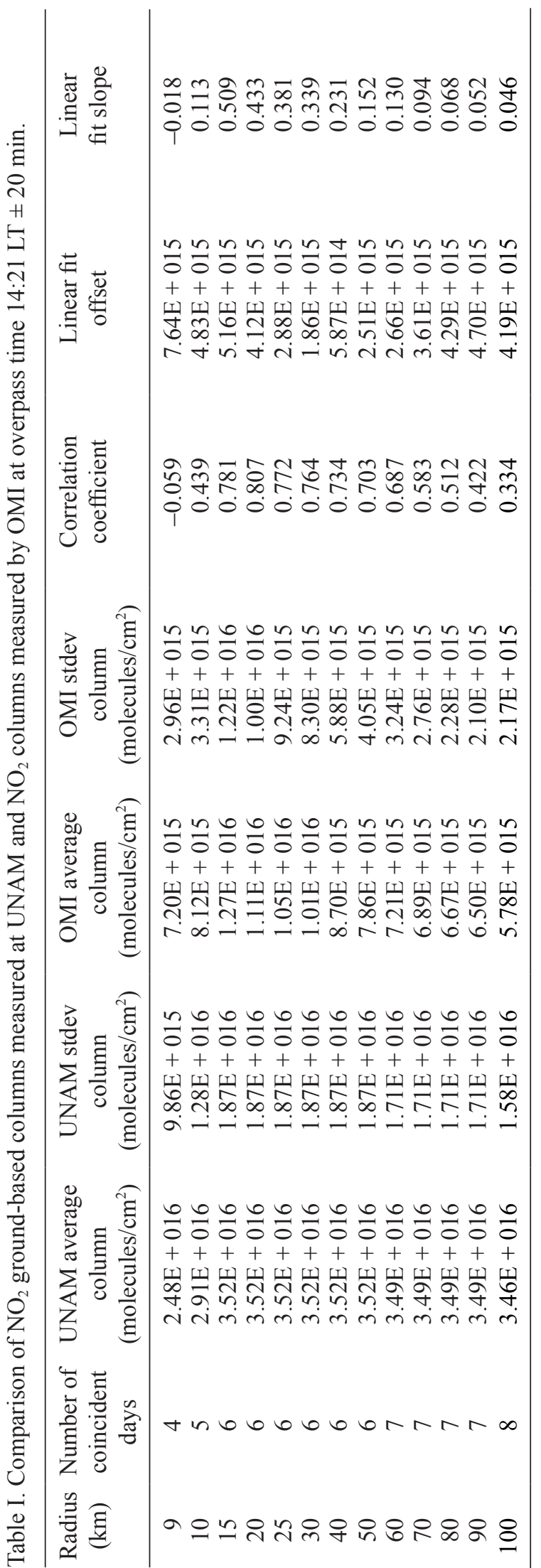


highest correlation coefficient $(0.807)$ was found when comparing OMI data with a pixel center falling within a $20 \mathrm{~km}$ radius around UNAM; however, good correlation was also observed for data with pixel centers of 15 to $50 \mathrm{~km}$ radius around the groundbased site.

The averages from $\mathrm{OMI} \mathrm{NO}_{2}$ columns shown in Table I, however, are underestimated since the instrument's footprint of $13 \times 24 \mathrm{~km}^{2}$ at nadir covers a large area and the UNAM site is within a region with large gradients in its horizontal distribution. A better representation of the fine structure is obtained by the reconstruction shown in Figure 4 according to the methodology described in section 2.1.1. The reconstructed value of the average over UNAM for the entire time period is $1.7 \times 10^{16}$ molecules $/ \mathrm{cm}^{2}$. This value is approximately three times lower than the average ground-based $\mathrm{NO}_{2}$ column measured over UNAM.

Furthermore, the satellite observation might not be sensitive enough close to the surface, where most of the pollution is present. A sensitivity of 0.5 would actually explain the difference by a factor of 2 between the mean values of the ground-based and space-borne DOAS measurements. The surface albedo of Mexico City in the $450 \mathrm{~nm}$ spectral region was measured by Castro et al. (2001) and recently during the MILAGRO field experiment by Coddington et al. (2008) and found to be in average around 0.05 and 0.07 respectively. Therefore, the estimated sensitivity of space-borne DOAS retrievals on surface near $\mathrm{NO}_{2}$ anomalies (local pollution in the mixing layer) should range between 0.2 and 0.7 , which correspond to the two examples for surface albedo, 0.02 and 0.15 , showed by Eskes and Boersma (2003).

Monthly average comparisons were also made between ground-based measurements, OMI and RAMA calculated $\mathrm{NO}_{2}$ columns (Fig. 7). Again, only ground-based measurements within \pm 20 min of the OMI overpass time ( 14:21 LT) above UNAM are kept. OMI averages were restricted to columns with pixel centers within \pm 0.1 degrees latitude/ longitude of UNAM. Ground-based reported RAMA $\mathrm{NO}_{2}$ columns were calculated from the average concentrations measured by five stations located near UNAM, multiplied by the measured mixing layer height (section 2.4) and correcting for pressure and temperature (section 2.5). A monthly cycle was clearly identified, however, it would seem to differ slightly depending on the origin of the data. The calculated columns from surface RAMA data were the highest, followed by the ground-based DOAS measurements and finally the OMI data yielded the lowest values. This result was expected since the ground-based RAMA stations sample $\mathrm{NO}_{2}$ at a single sampling point very close to the sources and/ or when it has just been recently converted. The DOAS ground-based measurements are conducted close to the sources as well, however, its location and vegetation around the UNAM campus could partly dampen the detection of $\mathrm{NO}_{2}$ at the current sampling point. Furthermore, while the groundbased DOAS instrument is sampling at a single point, the observed columns by OMI are effectively averaged over the instrument's field of view $(13 \times$ $24 \mathrm{~km}^{2}$ at nadir) yielding lower $\mathrm{NO}_{2}$ columns than the other two instruments probably because of the averaging of polluted and unpolluted areas.

\subsection{Spatial distribution of $\mathrm{NO}_{2}$ columns recons- tructed from UNAM measurements}

An additional analysis was made in the interest of gaining more information regarding the possible origin of the $\mathrm{NO}_{2}$ columns measured over UNAM, especially due to the inhomogeneous distribution of $\mathrm{NO}_{2}$ columns in the city, attested by OMI measurements. The averaged surface wind speed and wind direction measured at five stations near UNAM were used to compute the statistical wind propagation pattern that indicates the probability that a column measured at UNAM is originated or transported from a certain area of the city. Wind directions were analyzed on $30^{\circ}$ intervals, and a probability was assigned to each sector according to the relative frequencies. Each sector was differentiated into three regions according to the intervals of certain probability $(15.85,68.3$, and $15.85 \%$ ) related to different intervals of confidence of a log-normal distribution. Accordingly, wind speeds were expected to follow a log-normal distribution as well, described by the median and the log-normal standard deviation (Fig. 8a).

The false color of each region in Figure $8 \mathrm{a}$ indicates the probability that an airmass will be measured at UNAM with the certain time delay of $2.25 \mathrm{~h}$. This time delay used for the visualization (Fig. 8) is the estimated lifetime of $\mathrm{NO}_{2}$ in the mixing layer with a typical temperature of the Mexico City boundary layer and according to Dils (2008). The measured $\mathrm{NO}_{2}$ columns were then distributed to the corresponding 

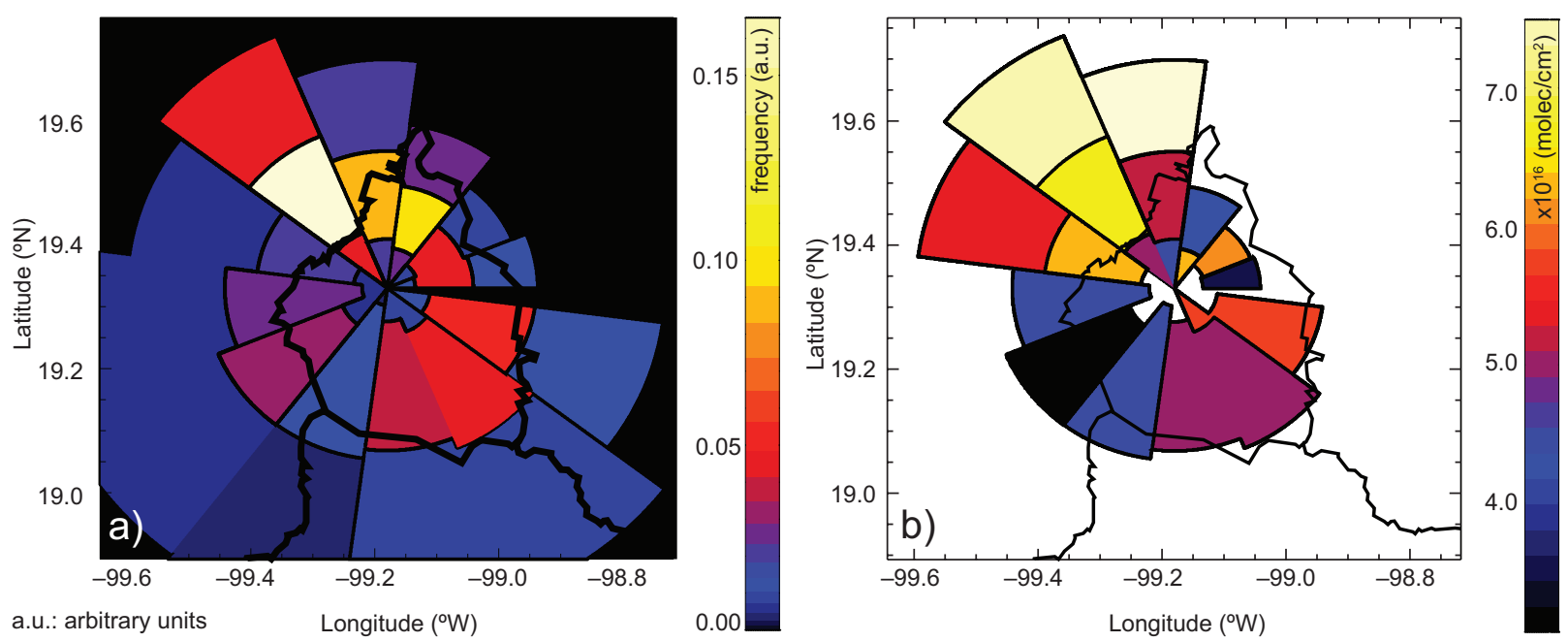

Fig. 8. (a) Frequency distribution of the air masses $2.25 \mathrm{~h}$ before measured at UNAM computed from wind data taken at RAMA stations; (b) distribution pattern of the averaged $\mathrm{NO}_{2}$ total columns $2.25 \mathrm{~h}$ before were measured at UNAM

sectors using wind direction and wind speed at the time when measurements were conducted. The distribution pattern of the averaged $\mathrm{NO}_{2}$ total columns reconstructed from the measurements at UNAM and wind measurements is presented in Figure $8 \mathrm{~b}$. The result of this approach indicates a tendency to measure higher $\mathrm{NO}_{2}$ columns when the wind direction is predominant from the north-northwest, coinciding with the most industrialized and populated area of the city.

\section{Conclusions}

$\mathrm{NO}_{2}$ columns were measured at UNAM in Mexico City and compared to space-borne observations conducted by the OMI instrument. Space-borne $\mathrm{NO}_{2}$ columns were lower than ground-based measurements, which presented large day-to-day variations. The difference between space-borne and ground-based columns could be explained by the strong horizontal inhomogeneity of the lower layer of the measured $\mathrm{NO}_{2}$ columns and by the difference in horizontal sensitivity of the two techniques (local versus averaging over $13 \times 24 \mathrm{~km}^{2}$ ). More instruments located in and around the MCMA would allow to better evaluate the spatial distribution obtained from satellite measurements. A network of several MAX-DOAS has already been installed starting the fall of 2012, which will result in better ground-based coverage and accuracy of the reported columns.

A reconstructed distribution of weighted $\mathrm{NO}_{2}$ columns over a fine grid was made over a large region in central Mexico, allowing to successfully define three main areas with enhanced pollution: the dominating metropolitan area of Mexico City, the heavily industrialized Tula region and the Cuernavaca valley. Other mayor urban areas such as Toluca and Puebla showed in average relatively lower column densities than Cuernavaca. The considerably higher altitude of Toluca probably favors the photolytic destruction of $\mathrm{NO}_{2}$, and this area does not appear to receive as much pollution from Mexico City, as the Cuernavaca valley. The importance of considering changes in albedo, aerosols load and their refractions indexes in $\mathrm{NO}_{2}$ photolysis rates should also be noted. The unanticipated enhancement of $\mathrm{NO}_{2}$ columns above the Cuernavaca valley, corroborates results from previous studies conducted by Melamed et al. (2009) and Salcedo et al. (2012), where a possible transport of pollutants from the MCMA have been discussed. A plausible source arising from the biomass burning activities in that region is suggested for the high $\mathrm{NO}_{2}$ columns detected.

From the reconstructed maps it is also possible to observe an important interconnection between the MCMA and the Tula industrial region, where emissions from one can evidently affect the other and the transport of pollutants between them most probably occurs. In addition, distinct seasonal variability of $\mathrm{NO}_{2}$ columns over central Mexico was found, concurring with previous studies, with higher $\mathrm{NO}_{2}$ columns measured during the dry and cold season, followed by the dry and warm period and finally the lowest $\mathrm{NO}_{2}$ columns were found during the rainy 
season. Furthermore, the spatial distribution of $\mathrm{NO}_{2}$ columns reconstructed from measurements conducted at UNAM indicate a tendency to measure higher $\mathrm{NO}_{2}$ columns when the wind direction is predominant from the north-northwest, coinciding with the most industrialized area of the city.

\section{Acknowledgements}

The authors gratefully acknowledge financial support provided by DGAPA-UNAM through project number IN119310 and a DGAPA-UNAM postdoctoral research scholarship. The OMI project is managed by the Netherlands Agency for Aerospace Programs (NIVR) and the Royal Netherlands Meteorological Institute (KNMI). The authors acknowledge the free use of $\mathrm{NO}_{2}$ total column data from the OMI sensor accessed via the NASA Aura Validation Data Center (AVDC) and Goddard Earth Science (GES) Data and Information Services Center (DISC). Caroline Fayt and Michel van Roozendael from the Belgian Institute for Space Aeronomie are acknowledged for the free use of the QDOAS software used for the evaluation of the ground-based data presented in this work. SIMAT and the SMA-GDF are thanked for providing the in situ measurements and the Programa de Estaciones Meteorológicas del Bachillerato Universitario (PEMBU) network is acknowledged for the meteorological data. Alfredo Rodríguez from the Centro de Ciencias de la Atmósfera workshop is acknowledged for providing technical support on the installation of the instrumentation used to conduct the ground-based measurements.

\section{References}

Beirle S., K. F. Boersma, U. Platt, M. G. Lawrence and T. Wagner, 2011. Megacity emissions and lifetimes of nitrogen oxides probed from space. Science 333, 1737-1739, doi:10.1126/science.1207824.

Bhartia P. K., 2002. OMI algorithm theoretical basis document. Vol. II. OMI ozone products. ATBD-OMI-02, Version 2.0. NASA Goddard Space Flight Center, Greenbelt, MD, 92 pp.

Boersma K. F., D. J. Jacob, E. J. Bucsela, A. E. Perring, R. Dirksen, R. J. van der A, R. M. Yantosca, R. J. Park, M. O. Wenig, T. H. Bertram and R. C. Cohen, 2008. Validation of OMI tropospheric $\mathrm{NO}_{2}$ observations during INTEX-B and application to constrain NOx emissions over the eastern United States and Mexico. Atmos. Environ. 42, 4480-4497.
Boersma K. F., D. J. Jacob, M. Trainic, Y. Rudich, I. DeSmedt, R. Dirksen and H. J. Eskes, 2009. Validation of urban $\mathrm{NO}_{2}$ concentrations and their diurnal and seasonal variations observed from the SCIAMACHY and OMI sensors using in situ surface measurements in Israeli cities. Atmos. Chem. Phys. 9, 3867-3879.

Brinksma E. J., G. Pinardi, H. Volten, R. Braak, A. Richter, A. Schönhardt, M. van Roozendael, C. Fayt, C. Hermans, R. J. Dirksen, T. Vlemmix, A. J. C. Berkhout, D. P. J. Swart, H. Oetjen, F. Wittrock, T. Wagner, O. W. Ibrahim, G. de Leeuw, M. Moerman, R. L. Curier, E. A. Celarier, A. Cede, W. H. Knap, J. P. Veefkind, H. J. Eskes, M. Allaart, R. Rothe, A. J. M. Piters and P. F. Levelt, 2008. The 2005 and 2006 DANDELIONS $\mathrm{NO}_{2}$ and aerosol intercomparison campaigns. J. Geophys. Res. 113, D16S46, doi:10.1029/2007JD008808.

Bucsela E. J., E. A. Celarier, M. O. Wenig, J. F. Gleason, J. P. Veefkind, K. F. Boersma and E. Brinksma, 2006. Algorithm for $\mathrm{NO}_{2}$ vertical column retrieval from the Ozone Monitoring Instrument. IEEE T. Geosci. Remote 44, 1245-1258, doi:10.1109/TGRS.2005.863715.

Burrows J. P., A. Richter, A. Dehn, B. Deters, S. Himmelmann, S. Voigt and J. Orphal, 1999. Atmospheric remote sensing reference data from GOME-2. Temperature dependent absorption cross-sections of $\mathrm{O}_{3}$ in the 231794 nm range. J. Quant. Spectrosc. Ra. 61, 509-517.

Castro T., B. Mar, R. Longoria and L. G. Ruiz-Suárez, 2001. Surface albedo measurements in Mexico City metropolitan area. Atmósfera 14, 69-74.

CCA-UNAM, 2008. Final report of project "Monitoreo y modelación de las emisiones a la atmósfera en Tula" prepared for Comisión Federal de Electricidad. Centro de Ciencias de la Atmósfera, Universidad Nacional Autónoma de México, Mexico.

Celarier E. A., J. F. Gleason, B. Bojkov, J. P. Veefkind, A. Cede, J. R. Herman, E. Brinksma, D. V. Ionov, T. P. Kurosu, J. C. Lambert, M. van Roosendael and E. J. Bucsela, 2006. Evaluation of $\mathrm{OMI} \mathrm{NO}_{2}$ data quality, available at: http://www.knmi.nl/omi/research/product/ NO2/OMNO2_data_quality_2006.pdf [last accessed on 15 February 2012].

Celarier E. A., E. J. Brinksma, J. F. Gleason, J. P. Veefkind, A. Cede, J. R. Herman, D. Ionov, F. Goutail, J. P. Pommereau, J. C. Lambert, M. van Roozendael, G. Pinardi, F. Wittrock, A. Schönhardt, A. Richter, O. W. Ibrahim, T. Wagner, B. Bojkov, G. Mount, E. Spinei, C. M. Chen, T. J. Pongetti, S. P. Sander, E. J. Bucsela, M. O. Wenig, D. P. J. Swart, H. Volten, M. Kroon and P. F. Levelt, 2008. Validation of Ozone Monitoring 
Instrument nitrogen dioxide columns. J. Geophys. Res. 113, D15S15, doi:10.1029/2007JD008908.

Chance K., 2002. OMI algorithm theoretical basis document. Vol. IV. OMI trace gas algorithms. ATBDOMI-02, Version 2.0. Smithsonian Astrophysical Observatory, Cambridge, 78 pp.

Chen D., B. Zhou, S. Beirle, L. M. Chen and T. Wagner, 2009. Tropospheric $\mathrm{NO}_{2}$ column densities deduced from zenith-sky DOAS measurements in Shanghai, China, and their application to satellite validation. Atmos. Chem. Phys. 9, 3641-3662.

Claas J. J., 2012. Notes on the releases of OMI data products, issue 1.2. KNMI, Netherlands, $10 \mathrm{pp}$.

Coddington O., K. S. Schmidt, P. Pilewskie, W. J. Gore, R. W. Bergstrom, M. Román, J. Redemann, P. B. Russell, J. Liu and C. C. Schaaf, 2008. Aircraft measurements of spectral surface albedo and its consistency with ground-based and space-borne observations. J. Geophys. Res. 113, D17209, doi:10.1029/2008JD010089.

Crutzen P. J., 1979. The role of $\mathrm{NO}$ and $\mathrm{NO}_{2}$ in the chemistry of the troposphere and stratosphere. Annu. Rev. Earth Pl. Sc. 7, 443-472.

De Foy B., N. A. Krotkov, N. Bei, S. C. Herndon, L. G. Huey, A. P. Martínez, L. G. Ruiz-Suárez, E. C. Wood, M. Zavala and L. T. Molina, 2009. Hit from both sides: tracking industrial and volcanic plumes in Mexico City with surface measurements and $\mathrm{OMI} \mathrm{SO}_{2}$ retrievals during the MILAGRO field campaign. Atmos. Chem. Phys. 9, 9599-9617, doi:10.5194/acp-9-9599-2009.

Dils B., 2008. Long range transport of tropospheric $\mathrm{NO}_{2}$ as simulated by FLEXPART. Product Specification Document TEM/LRT2/001, version 0.2, TEMIS, De Bilt, The Netherlands.

Dirksen R. J., K. F. Boersma, H. J. Eskes, D. V. Ionov, E. J. Bucsela, P. F. Levelt and H. M. Kelder, 2011. Evaluation of stratospheric $\mathrm{NO}_{2}$ retrieved from the Ozone Monitoring Instrument: Intercomparison, diurnal cycle, and trending. J. Geophys. Res. 116, D08305, doi:10.1029/2010JD014943.

Eskes H. J. and K. F. Boersma, 2003. Averaging kernels for DOAS total-column satellite retrievals. Atmos. Chem. Phys. 3, 1285-1291.

Fayt C., I. DeSmedt, V. Letocart, A. Merlaud, G. Pinardi and M. Van Roozendael, 2011. QDOAS Software user manual. Belgian Institute for Space Aeronomie, 71 pp.

Gruzdev A. N. and S. Elokhov, 2010. Validation of Ozone Monitoring Instrument $\mathrm{NO}_{2}$ measurements using ground based $\mathrm{NO}_{2}$ measurements at Zvenigorod, Russia. Int. J. Remote Sens. 31, 497-511.
Herman J., A. Cede, E. Spinei, G. Mount, M. Tzortziou and $\mathrm{N}$. Abuhassan, 2009. $\mathrm{NO}_{2}$ column amounts from groundbased Pandora and MFDOAS spectrometers using the direct-sun DOAS technique: Intercomparisons and application to OMI validation. J. Geophys. Res. 114, D13307, doi:10.1029/2009JD011848.

Hermans C., A. C. Vandaele, M. Carleer, S. Fally, R. Colin, A. Jenouvrier, B. Coquart and M. F. Mérienne, 1999. Absorption cross-sections of atmospheric constituents: $\mathrm{NO}_{2}, \mathrm{O}_{2}$, and $\mathrm{H}_{2} \mathrm{O}$, Environ. Sci. Pollut. R. 6, 151-158. Herron-Thorpe F. L., B. K. Lamb, G. H. Mount and J. K. Vaughan, 2010. Evaluation of a regional air quality forecast model for tropospheric $\mathrm{NO}_{2}$ columns using the $\mathrm{OMI} /$ Aura satellite tropospheric $\mathrm{NO}_{2}$ product. Atmos. Chem. Phys. 10, 8839-8854.

Huijnen V., H. J. Eskes, A. Poupkou, H. Elbern, K. F. Boersma, G. Foret, M. Sofiev, A. Valdebenito, J. Flemming, O. Stein, A. Gross, L. Robertson, M. D'Isidoro, I. Kioutsioukis, E. Friese, B. Amstrup, R. Bergstrom, A. Strunk, J. Vira, D. Zyryanov, A. Maurizi, D. Melas, V. H. Peuch and C. Zerefos, 2010. Comparison of OMI $\mathrm{NO}_{2}$ tropospheric columns with an ensemble of global and European regional air quality models. Atmos. Chem. Phys. 10, 3273-3296.

Ionov D. V.,Y. M. Timofeyev, V. P. Sinyakov, V. K. Semenov, F. Goutail, J. P. Pommereau, E. J. Bucsela, E. A. Celarier and M. Kroon, 2008. Ground-based validation of EOS-Aura $\mathrm{OMI} \mathrm{NO}_{2}$ vertical column data in the mid-latitude mountain ranges of Tien Shan (Kyrgyzstan) and Alps (France). J. Geophys. Res. 113, D15S08, doi:10.1029/2007JD008659.

Irie H., Y. Kanaya, H. Akimoto, H. Tanimoto, Z. Wang, J. F. Gleason and E. J. Bucsela, 2008. Validation of OMI tropospheric $\mathrm{NO}_{2}$ column data using MAX-DOAS measurements deep inside the North China Plain in June 2006: Mount Tai Experiment 2006. Atmos. Chem. Phys. 8, 6577-6586.

Kim S. W., A. Heckel, G. J. Frost, A. Richter, J. Gleason, J. P. Burrows, S. McKeen, E. Y. Hsie, C. Granier and M. Trainer, 2009. $\mathrm{NO}_{2}$ columns in the western United States observed from space and simulated by a regional chemistry model and their implications for NOx emissions. J. Geophys. Res. 114, D11301, doi:10.1029/2008JD011343.

Kraus S., 2006. DOASIS: A framework design for DOAS. $\mathrm{PhD}$ Thesis. Mannheim University.

Levelt P. F., E. Hilsenrath, G. W. Leppelmeier, G. H. J. van den Oord, P. K. Bhartia, J. Tamminen, J. F. de Haan and J. P. Veefkind, 2006a. Science objectives 
of the Ozone Monitoring Instrument. IEEE T. Geosci. Remote 44, 1199-1208.

Levelt P. F., G. H. J. van den Oord, M. R. Dobber, A. Malkki, H. Visser, J. de Vries, P. Stammes, J. Lundell and H. Saari, 2006b. The Ozone Monitoring Instrument. IEEE T. Geosci. Remote 44, 1093-1101, doi:10.1109/ TGRS.2006.872333.

Lin J. T., 2012. Satellite constraint for emissions of nitrogen oxides from anthropogenic, lightning and soil sources over East China on a high-resolution grid. Atmos. Chem. Phys. 12, 2881-2898.

Melamed M. L., R. Basaldud, R. Steinbrecher, S. Emeis, L. G. Ruiz-Suárez and M. Grutter, 2009. Detection of pollution transport events southeast of Mexico City using ground-based visible spectroscopy measurements of nitrogen dioxide. Atmos. Chem. Phys. 9, 4827-4840.

Münkel C., N. Eresmaa, J. Räsänen and A. Karppinen, 2007. Retrieval of mixing height and dust concentration with lidar ceilometer. Bound.-Lay. Meteorol. 124, 117-128.

OMI Team, 2009. Ozone Monitoring Instrument (OMI) Data User's Guide. OMI-DUG-3.0. NASA, U.S.A., $62 \mathrm{pp}$.

Platt U. and J. Stutz, 2008. Differential optical absorption spectroscopy (DOAS). Principle and applications. Springer, Heidelberg, 597 pp.

Rees W. G., 2001. Physical principles of remote sensing. Cambridge University Press, Cambridge, 343 pp.

Salcedo D., T. Castro, L. G. Ruiz-Suárez, A. García-Reynoso, R. Torres-Jardón, A. Torres-Jaramillo, B. E. Mar-Morales, A. Salcido, A. T. Celada, S. Carreón-Sierra, A. P. Martínez, O. A. Fentanes-Arriaga, E. Deustúa, R. Ramos-Villegas, A. Retama-Hernández, M. I. Saavedra and M. Suárez-Lastra, 2012. Study of the regional air quality south of Mexico City (Morelos state). Sci. Total Environ. 414, 417-432.

SMA-GDF, 2010. Inventario de emisiones de contaminantes criterio de la ZMVM 2008. Gobierno del Distrito Federal, Secretaría del Medio Ambiente, Mexico, 62 pp.

Solomon S., A. L. Schmeltekopf and R. W. Sanders, 1987. On the interpretation of zenith sky measure- ments. J. Geophys. Res. 92, 8311-8319, doi:10.1029/ JD092iD07p08311.

Stremme W., M. Grutter, C. Rivera, A. Bezanilla, A. R., García, I. Ortega, M. George, C. Clerbaux, P. F. Coheur, D. Hurtmans, J. W. Hannigan and M. T. Coffey, 2013. Top-down estimation of carbon monoxide emissions from the Mexico megacity based on FTIR measurements from ground and space. Atmos. Chem. Phys. 13, 1357-1376, doi:10.5194/acp-131357-2013, 2013.

UN, 2012. World population prospects: The 2010 revision and world urbanization prospects: The 2011 revision. Population Division of the Department of Economic and Social Affairs of the United Nations Secretariat, available at: http://esa.un.org/wpp/Documentation/ publications.htm [last accessed on 15 February 2012]. Valin L. C., A. R. Russell, E. J. Bucsela, J. P. Veefkind and R. C. Cohen, 2011. Observation of slant column $\mathrm{NO}_{2}$ using the super-zoom mode of AURA-OMI. Atmos. Meas. Tech. 4, 1929-1935.

Vandaele A. C., C. Hermans, P. C. Simon, M. Carleer, R. Colin, S. Fally, M. F. Merienne, A. Jenouvrier and B. Coquart, 1998. Measurements of the $\mathrm{NO}_{2}$ absorption cross-section from $42000 \mathrm{~cm}^{-1}$ to $10000 \mathrm{~cm}^{-1}$ (238$1000 \mathrm{~nm})$ at $220 \mathrm{~K}$ and 294 K. J. Quant. Spectrosc. Ra. 59, 171-184.

Vlemmix T., A. J. M. Piters, P. Stammes, P. Wang and P. F. Levelt, 2010. Retrieval of tropospheric $\mathrm{NO}_{2}$ using the MAX-DOAS method combined with relative intensity measurements for aerosol correction. Atmos. Meas. Tech. 3, 1287-1305.

Wallace J. and P. Kanaroglou, 2009. The sensitivity of OMI-derived nitrogen dioxide to boundary layer temperature inversions. Atmos. Environ. 43, 35963604.

Wenig M. O., A. M. Cede, E. J. Bucsela, E. A. Celarier, K. F. Boersma, J. P. Veefkind, E. J. Brinksma, J. F. Gleason and J. R. Herman, 2008. Validation of OMI tropospheric $\mathrm{NO}_{2}$ column densities using direct-Sun mode Brewer measurements at NASA Goddard Space Flight Center. J. Geophys. Res. 113, D16S45, doi:10.1029/2007JD008988. 